\title{
Łukasz Wojtkowski. 2010. Kultura masowa a marketing polityczny. Przypadek amerykańskich kampanii prezydenckich 2000 i 2004. Toruń: Wydawnictwo Adam Marszałek, ss. 131
}

B ez wątpienia kultura masowa, podobnie jak komunikacja masowa, charakteryzuje się wyraźną „siłą rażenia” [Cwalina, Falkowski 2006: 241]. Jest wszechobecna, dominująca i wszystko wskazuje na to, że w najbliższym czasie stanie się immanentną częścią dyskursu politycznego, o ile już się to nie stało. W tym kontekście lektura książki autorstwa Łukasza Wojtkowskiego Kultura masowa a marketing polityczny. Przypadek amerykańskich kampanii prezydenckich 2000 i 2004 jest godna uwagi i zainteresowania.

Marketing polityczny to „zespół teorii, metod, technik i praktyk społecznych mających na celu przekonanie obywateli, by udzielili poparcia człowiekowi, grupie lub projektowi politycznemu" [Ulicka 1996: 157]. Marketing polityczny stanowi więc środek socjotechniczny wprowadzający do porządku społecznego nowe postrzeganie polityki. Można wręcz pokusić się o myśl, że jest on instrumentem wychowania dla demokracji liberalnej, a raczej dla jej nowej postaci - demokracji masowej [Pawełczyk 2007: 12]. Czy jest to jednak prawda? Czy tak sformułowana teza jest w ogóle do „obronienia”? W odpowiedzi na te i wiele innych pytań może pomóc lektura recenzowanej książki Łukasza Wojtkowskiego, ale czy na pewno?

Ostatnimi czasy rynek wydawniczy zdaje się zalewany publikacjami dotyczącymi marketingu, a marketingu politycznego w szczególności. Wśród tych pozycji tylko nieliczne są godne chwili uwagi i komentarza. Wyjątek stanowi recenzowana praca. Jej niezwykłość polega głównie na ujęciu problemu, które może być mylące, gdyż sugeruje, że kultura masowa stoi w opozycji do marketingu politycznego. Tymczasem, jak wynika z lektury książki, jest zgoła odwrotnie, tzn. „kultura masowa wpływa również na marketing polityczny" [Wojtkowski 2010: 5].

Niewiele jest publikacji dotykających zagadnienia kultury i marketingu. Z tym większym zainteresowaniem recenzent przystąpił do lektury omawianej książki, która (ze względu na objętość pracy - 88 stron bez aneksu) nie była zbyt trudna w przeciwieństwie do treści. Ta bowiem wymaga podstawowej wiedzy dotyczącej zagadnień związanych z szeroko pojętym marketingiem politycznym, kulturą polityczną i budową amerykańskiego systemu politycznego. Choć wiele jest w pracy fragmentów poświęconych historii political marketing - i dobrze. 
Recenzowana książka składa się ze wstępu, trzech rozdziałów, aneksu i bibliografii. Autor w spisie treści wyodrębnił także wnioski końcowe pod dyskusyjnym i prowokującym tytułem: „Wyjątkowa Ameryka”. We wstępie zostały zamieszczone podstawowe informacje, tj. cel pracy, ogólna struktura książki oraz obszar badań: kultura masowa i marketing polityczny na gruncie amerykańskim. W rozdziale pierwszym, zatytułowanym Marketing polityczny a kultura masowa - specyfika amerykańska, została opisana istota kultury masowej i marketingu politycznego. Autor umieścił w nim również informacje dotyczące mediów masowych, słusznie uznając je za „główne składowe kultury masowej i komunikacji masowej, na której bazuje polityka" [Wojtkowski 2010: 16].

Warto podkreślić, że wśród mediów Łukasz Wojtkowski wymienił: prasę, książkę, radio, film (kino), telewizję, plakat i muzykę. Zastanawia natomiast dość pobieżna refleksja dotycząca ujęcia definicyjnego i teoretycznego marketingu politycznego. Co prawda, autor odwołuje się do kilku istotnych publikacji (krajowych i zagranicznych), jednak w tym zakresie czytelnik (szczególnie obeznany z tematyką) może mieć niedosyt. Można wysunąć argument, że na rynku wiele jest publikacji dotykających tej tematyki i wyczerpujących problem teoretyzowania „o marketingu politycznym". Niemniej poruszanie kwestii marketingu w kulturze masowej, moim zdaniem, zobowiązuje. Za niezwykle ciekawe i intrygujące należy natomiast uznać spojrzenie Łukasza Wojtkowskiego na środki masowego komunikowania, które aż prosi się o większą liczbę przykładów, nieobecnych w recenzowanej pracy.

Niezwykle frapująca jest zawartość rozdziału drugiego: Kampania prezydencka 2000 - wizerunek polityczny liderów a jego społeczny odbiór, oraz trzeciego: Kampania prezydencka 2004 - media i kultura masowa. Zamieszczone w nich informacje są ciekawe i ważne. Stanowią ponadto doskonałą egzemplifikację tezy zawartej już na wstępie pracy. Autor, opisując kampanie wyborcze 2000 i 2004 roku, szczegółowo i konsekwentnie analizuje przebieg dwóch wielkich batalii wyborczych odbywających się w państwie, w którym „narodził się" marketing polityczny i ukonstytuowała się kultura masowa. Za godny uwagi i zasługujący na pochwałę należy również uznać fakt opisania przez Łukasza Wojtkowskiego przebiegu kampanii wyborczej w kontekście programu dwóch głównych partii amerykańskich (Partii Republikańskiej i Partii Demokratycznej) tworzonego na czas elekcji. Natomiast dyskusyjne może wydawać się badanie przebiegu wyborów z 2000 i 2004 roku na podstawie kryteriów charakterystycznych dla kampanii postmodernistycznej (takie bowiem założenie, niekoniecznie słusznie, dostrzega recenzent), kiedy coraz częściej wysuwa się argument, że obecnie mamy do czynienia (także, a może przede wszystkim w Stanach Zjednoczonych) z kampanią permanentną ${ }^{1}$ Nie do końca uprawniona wydaje się również teza autora, iż mediaty-

${ }^{1}$ Na gruncie polskim rozróżnienia kampanii postmodernistycznej i permanentnej dokonał m.in. Jan Garlicki. Jednak sama koncepcja kampanii „nieustającej” w marketingu 
zacja (którą Łukasz Wojtkowski postrzega jako synonim hollywoodyzacji) polega przede wszystkim na przeznaczaniu ogromnych środków finansowych, zatrudnianiu sztabów specjalistów, produkowaniu filmów reklamowych w ramach prowadzonej kampanii wyborczej, słowem - przemianach popkulturowych w rozumieniu kultury masowej [Wojtkowski 2010: 64]. W publikacjach poświęconych tej tematyce pojawia się bowiem nieco inne ujęcie, według którego mediatyzacja to przede wszystkim ciągły i niepohamowany wzrost roli i znaczenia środków społecznego przekazu w prezentowaniu treści politycznych [Inglik-Dziąg 2007: 24]. Czy też dosłownie - komentowanie przez media działań elit politycznych, poddawanie ich pod dyskusję, ich osąd i krytyka [Dobek-Ostrowska, Wiszniowski 2001: 125]. Niezależnie od tego lektura tych rozdziałów jest niezwykle zajmująca i wartościowa.

Treści zawarte w poszczególnych rozdziałach Łukasz Wojtkowski podsumowuje we wnioskach końcowych, w których porusza nie tylko kwestię relacji marketing polityczny-kultura masowa, ale także próbuje nakreślić sytuację społeczno-polityczną w USA. Bardzo ciekawe są również rekomendacje dotyczące zaangażowania obywateli amerykańskich, znaczenia nieformalnych grup i stowarzyszeń coraz częściej angażujących się w rywalizację wyborczą. O trafności i przenikliwości tych rozważań świadczy to, co wydarzyło się w Stanach Zjednoczonych w 2008 roku w ramach kampanii Obama for America, a czego wszyscy byliśmy "naocznymi” świadkami i co sygnalizował w swojej książce Wojtkowski.

Całość recenzowanej publikacji zamyka aneks, w którym autor zamieścił teksty najważniejszych kampanijnych wystąpień, debat, przemówień inauguracyjnych oraz grafiki obrazujące najważniejsze wydarzenia opisywanych elekcji. Jak podkreślił sam autor: „Materiały zamieszczone w aneksie stanowią egzemplifikację dla treści książki" [Wojtkowski 2010: 89].

Marketing polityczny jest [...] wyrazem uwzględniania przy tworzeniu projektów i programów politycznych oraz ich promocji instrumentów badań oraz środków komunikacji istniejących we współczesnych społeczeństwach (badania opinii publicznej, media, w tym zwłaszcza telewizja i Internet, reklama, public relations), zaś wiele czynników, w tym w szczególności kultura polityczna elit i społeczeństwa, decyduje o tym, czy wykorzystywane będą one w sposób odpowiadający przyjętym w państwach demokratycznych standardom etycznym, czy też w sposób moralnie naganny, jakie działania spotkają się z aprobatą czy przyzwoleniem społecznym, jakie natomiast zostaną zakwestionowane, poddane krytyce i odrzucone [Ulicka 2010: 12-13].

politycznym funkcjonuje już od lat 80. XX w. i jest wiązana z prezydenturą Ronalda Reagana, a nawet Jimmy'ego Cartera [Garlicki 2010: 33]. 
Tak zakreślony aspekt definicyjny pozwala wskazać także na kulturę masową jako ten element, który należy uwzględnić przy próbach odpowiedzi na pytanie, czym właściwie jest marketing polityczny i jakie ma znaczenie we współczesnej aktywności politycznej. Posiłkując się słowami autora recenzowanej książki, można wręcz powiedzieć, że dokładna analiza kultury masowej i marketingu politycznego skłania do uznania, jakoby „posiadały one elementy wspólne”; „że jedna determinuje drugą" [Wojtkowski 2010: 83]. W tym sensie praca Łukasza Wojtkowskiego może stanowić wsparcie w poszukiwaniu odpowiedzi na pytania postawione na wstępie tej recenzji, a pośrednio zawarte także w omawianej publikacji.

Książka Łukasza Wojtkowskiego Kultura masowa a marketing polityczny. Przypadek amerykańskich kampanii prezydenckich 2000 i 2004 to nowe i intrygujące spojrzenie na marketing polityczny i jego coraz większą zażyłość z kulturą masową. Omawiana publikacja to również ciekawy opis tego, jak proces budowania i wdrażania strategii wyborczej był/jest realizowany w jednej z najstarszych demokracji liberalnych współczesnego świata, która jednocześnie była miejscem narodzin tego, co dziś nazywamy marketingiem politycznym. Niniejszą książkę należy uznać za oryginalne osiągnięcie naukowe (za naukowe opracowanie uznał je autor recenzji), które bez wątpienia wymagało wiele pracy, wysiłku i - co należy podkreślić - znajomości języka obcego (angielskiego). Jest to dobra pozycja, godna polecenia tym wszystkim, którzy choć trochę interesują się tematyką polityczną, a marketingiem politycznym w szczególności. Świeżości dodaje tej pracy fakt przyjęcia nieco innej perspektywy badawczej, nieczęstej wśród osób podejmujących problematykę political marketing. Z tym większym uznaniem i pewną zazdrością autor recenzji umieścił tę książkę w swojej domowej bibliotece, zachęcając do tego innych.

\section{Bibliografia}

Cwalina Wojciech, Falkowski Andrzej. 2006. Marketing polityczny. Perspektywa psychologiczna. Gdańsk: Gdańskie Wydawnictwo Psychologiczne.

Dobek-Ostrowska Bogusława, Wiszniowski Robert. 2001. Teoria komunikowania publicznego i politycznego. Wprowadzenie. Wrocław: Astrum.

Garlicki Jan. 2010. Komunikowanie polityczne - od kampanii wyborczej do kampanii permanentnej. „Studia Politologiczne” nr 16, s. 26-45.

Inglik-Dziąg Dorota. 2007. Rzeczywistość wirtualna - rola mediów w pośredniczeniu doświadczenia rzeczywistości w społeczeństwie masowym i ponowoczesnym. "Studia Medioznawcze" nr 4, s. 23-39.

Pawełczyk Piotr. 2007. Socjotechnika czy marketing polityczny?. [W:] P. Pawełczyk (red.). Marketing polityczny. Szansa czy zagrożenie dla współczesnej demokracji. Poznań: Wydawnictwo Naukowe INPID UAM. 
Ulicka Grażyna. 1996. Wpływ marketingu politycznego na zmiany w życiu publicznym państw demokratycznych. „Studia Politologiczne” nr 1, s. 157-167.

Ulicka Grażyna. 2010. Marketing polityczny a treści i postrzeganie polityki. „Studia Politologiczne" nr 16, s. 11-25.

Wojtkowski Łukasz. 2010. Kultura masowa a marketing polityczny. Przypadek amerykańskich kampanii prezydenckich 2000 i 2004. Toruń: Wydawnictwo Adam Marszałek.

Łukasz Scheffs

(Uniwersytet im. Adama Mickiewicza w Poznaniu) 